\title{
ANALYSIS OF THE FOREIGN MALIGN INFLUENCE IN MONTENEGRO
}

2019-2021

Pregledni rad (Review Paper)

Received: 14 November 2021

Accepted: 7 December 2021

DOI: https://doi.org/10.37458/nstf.22.3.6

\section{Ljubomir Filipović*}

\begin{abstract}
For many years now, the Republic of Montenegro has been facing numerous threats of a hybrid nature that are aggressively attacking its national and state-building identity. The level and intensity of malicious activities has changed over the years, from assassination attempts to inciting (and violent) protests in the streets to influence the election process. This analysis will show how operations of influence, planned and conducted by various actors from Russia and Serbia, with the use of internal
\end{abstract}

* Ljubomir Filipović is a political scientist and activist from Montenegro. He works as a consultant and analyst for different governmental, nongovernmental and private institutions. He is the leader of the "May 21st" Civic Initiative in Montenegro. He served his community as a Deputy and Acting Mayor of Budva and Political Advisor to Members of Parliament. He can be reached via email ljubomir.filipovic@gmail.com. 
freedoms and vulnerabilities, have led to a strong polarization of society and the state.

Keywords: Montenegro, hybrid threats, Serbia, Russia, Serbian orthodox church, influence operations

\section{INTRODUCTION}

The main goal of this analysis is to demonstrate how foreign malign influence mostly coming from Serbia and Russia has changed the social fabric of Montenegro and the ways in which recent history has played a critical role in the nature and scope of the political changes in the country following the 2020 elections.

The Balkans region remains one of the most significant global security challenges and remains a zone of friction where many global influences and spheres of interest meet. Therefore, even a small country like Montenegro sometimes finds itself playing a role that significantly exceeds its size and importance on the global political stage. Since Roman times, the territory of present-day Montenegro has been a borderland, and if you take a look at the map and the borderline between the Eastern and Western Roman empire at the time of the split, it almost perfectly cuts Montenegro in half. The same border has had many reincarnations over time, as the frontier between the Republic of Venice and the Ottoman Empire, between Napoleon and the Ottomans, and between the Habsburgs and the Ottomans.

If we fast forward to 2016, Montenegro is about to join NATO after a decade-long process of integration and negotiation. The parties that had supported Montenegrin NATO membership won the overwhelming majority in the parliamentary elections organized that year.

On the very election day in 2016 , a coup attempt took place. The coup attempt was allegedly financed and organized by the 
Russian intelligence services. According to Belingcatt ${ }^{1}$, and other relevant sources ${ }^{2}$, it was carried out by the very same people and organizations in the Russian security apparatus that were later accused of involvement in the Salisbury poisoning attempt in 2018, and the Navalny poisoning case.

Moving forward to 2020, and the most recent parliamentary elections in the country, we find that significant political changes took place. The three-decades-long rule of a predominant party ended. One government burdened with corruption and state capture was replaced by another one formed by a coalition of coalitions which was led by some of the main actors of the 2016 Russian-sponsored coup attempt.

The political changes in the country were the result of a combination of different processes. As I mentioned before: the rule of one party burdened with corruption and organized crime, the COVID pandemics, and the related economic crisis that followed, created the perfect storm for Serbia and Russia to lock in their long-awaited profits in the country.

\section{ORIGINS OF RUSSIAN INFLUENCE}

Russophilia is not a new phenomenon in Montenegro. During the Ottoman times, the Russian Empire acted as a guarantor of the rights of the Orthodox Slavic population in the Balkans, and it was a sponsor to the Montenegrin theocracy at that time. Some of the Montenegrin rulers, the Prince-bishops of the PetrovicNjegos dynasty, were enthroned in Saint Petersburg, while the state budget was greatly subsidized from Russian imperial funds. Two daughters of the Montenegrin King were married to very high-ranking Romanov family members. The Montenegrin sense of closeness to the Russians, which is almost a sense of kinship, has been often ridiculed by our Balkan neighbors through a mock saying "Nas I Rusa 300 miliona" which loosely translates as "There are 300 million of us, together with the Russians". After the Cold War ended, and after the

1. https://www.bellingcat.com/resources/podcasts/2020/06/16/bellingchatepisode-3-hunting-the-the-salisbury-poisonings-suspects/

2. https://www.nytimes.com/2019/05/09/world/europe/montenegro-coup-plotgru.html 
reemergence of Russian regional and global appetites, their influence and impact reemerged in the Balkans, mostly through the work of the Russian and Serbian Orthodox Churches and extremist political movements which advocate for closer cooperation with Russia at all levels.

\section{THE RUSSIAN GOVERNMENT AND ITS APPROACH}

The Russian government issued numerous statements on their view of Montenegrin NATO membership. They were publicly expressing their discontent with the Montenegrin decision to join NATO, though these messages grew louder still with every single Montenegrin decision to align with the Western sanctions against the Russian Federation because of Russian actions against Georgia and Ukraine, and the hostile actions of the Russian intelligence services in various European countries. Countermeasures, most notably economic sanctions against Montenegro, were introduced by the Russian authorities. The Russian embassy in Podgorica has generally kept a low profile in an attempt to remain "neutral", while most of the propaganda work has been done through the office of the Honorary Consul, a very colorful local businessman who has been sponsoring political movements, and other Russian organizations, in recent years.

When it comes to soft power, the Russian Federation Embassy in Montenegro has clearly become more active over the years. Rossotrudnichestvo, the Russian State Agency, finances scholarships for Montenegrins who are studying in Russia. They are giving grants to different security and other strategic conferences that resemble those sponsored by NATO allies across Western Europe. Most of these political conferences were held in Belgrade with participants from Montenegro. After the change of government in Montenegro in 2020, one of the most active organizers and participants of these Russiansponsored seminars became the Rector of the State University in Montenegro, the largest and most significant higher education body in the country.

It would appear that the Russians are learning how to use various methods of public diplomacy as well. This is most clearly 
shown by the fact that local Montenegrin journalists have been invited on promotional tours of Moscow by the Russian government; these tours have also on occasion included visits to Grozny ${ }^{3}$, where meetings with political figures such as Ramzan Kadyrov and his generals have been arranged. In rare instances, Montenegrin journalists have been invited to visit Russian-occupied Crimea. All of these soft-power activities have been aimed at altering both the perception of Russia in Montenegro and the narrative around the direction of travel of Montenegrin foreign policy aims and intentions.

\section{THE RUSSIAN MEDIA}

The Russian media, and especially the part of it which is controlled by the government launched a campaign of fear aimed at the Russian public a year before Montenegro officially joined NATO in 2017. The false narrative of NATO military bases in Montenegro was omnipresent in the Russian media. In 2019. after the Montenegrin government decided to pass the Law on the Freedom of Religion, protests were launched by the Serbian Orthodox Church, and Russian media correspondents swarmed the Montenegrin coast, sending home reports with sensationalist headlines which dominated the media narrative of Russian newspapers and political talk shows. Such sensationalist headlines included claims such as "The Police in Montenegro refused to guarantee the safety of Mass processions", while various narratives were spread, based on such concepts as "the betrayal of the Slavic brotherhood" "the attack on the Orthodox religion" and the actions of the "criminal leaders in Montenegro."

Apart from media directly produced in Russia, the Serbian desk of the state-controlled media concern Sputnik, and several regional desks of "Russia Beyond", have been very active in covering Montenegrin politics in recent years. Moreover, local journalists and their reports have been organized and published across numerous pro-Russian web portals such as Balkanist.ru.

3. https://hr.rbth.com/travel/86156-nasa-reportaza-cecenija

4. https://ria.ru/20170228/1488903745.html 


\section{RUSSIAN NON-STATE ACTORS}

A good question here is in fact to consider if there is such a thing as a non-state actor in the context of contemporary Russia. Starting with the Russian Orthodox Church, and religious paramilitary organizations like the Cossack Armies, the Night Wolves, and the Immortal Regiment, we find a pattern of these actors all working closely together in promoting the "values" of the Russian World in Montenegro and the wider region - in this context, the most important of these concepts are Orthodox clericalism, authoritarianism, and nationalism ${ }^{5}$. During the Church-led protests in 2020, the Serbian Church drew specific parallels with the situation in Russia, and Metropolitan Onufriy, the head of the Russian Church in Ukraine (the UOC, which operated under the Moscow Patriarchate) went as far as to take part in demonstrations on the streets of Montenegrin capital ${ }^{6}$. In research I conducted for Montenegro's Atlantic Council, we discovered connections between the Russian Honorary Consul and all of these organizations in Montenegro. He has financed a pro-Russian political party that now holds ${ }^{7}$ high offices in the government - counting the Secretary-General of the government among its members, for instance. He also founded the Montenegrin chapters of Night Wolves, the Balkans Cossacks Army, and Sorok Sorokov, a far-right religious organization with army-like discipline.

His semi-official role in the organization and financing of these "non-state actors" is a clear indication of the wider Russian approach to engagement in and influence over Montenegro and its political and religious life over recent years. The consul, who is a Montenegrin citizen, was even subpoenaed by the Russian courts for his role in a criminal case against one of the highranking FSB officers. ${ }^{8}$

5. Kudors, Andis (16 June 2010). "'Russian World"-Russia's Soft Power Approach to Compatriots Policy" (PDF). Russian Analytical Digest. Research Centre for East European Studies. 81

6. https://balkaninsight.com/2020/02/26/russian-backed-bishop-joinsmontenegro-church-protests/

7. https://m.cdm.me/arhiva/izbori-2018/predsjednicki/ruski-konzul-dukicosnivac-milaciceve-prave-crne-gore/

8. https://www.rbc.ru/society/02/11/2021/6180c9b29a7947b0f7e6a9b9 


\section{SERBIAN INFLUENCE}

Serbia and Montenegro have long been perceived as kin states in the Western Balkans. This to many represents a mini version of the Germany-Austria or Ukraine-Russia relationships, which in the case of Serbia and Montenegro involves the manipulation of identity politics, Serbian economic interests, and the interests of the Serbian Church. Montenegro was occupied by Serbia in 1918, its king was exiled, and the separate status of the autocephalous Montenegrin Church was abolished; this was all carried out in a deliberate attempt to erase both Montenegrin statehood and a separate, defined Montenegrin identity.

Montenegro regained part of its sovereignty after 1945, and finally, after Milosevic's catastrophic FRY experiment, the country became fully independent again in 2006 .

Even though Serbia, which was at the time weakened by its own political turmoil, Kosovo and Republika Srpska, the Serbian political entity that forms part of Bosnia and Herzegovina, acknowledged the Montenegrin referendum results in 2006, it is clear that through the manipulation of identity politics in the country, as well as through the various activities of state and non-state actors, the Serbian political and religious establishment have contributed to the radicalization of those people living in Montenegro who identify themselves as Serbs. Here, we need to emphasize something that is usually overlooked when it comes to Montenegro. Unlike in the other countries in the region, where you have a clear ethnic distinction between Serbs and other ethnicities, in Montenegro, the difference between Serbs and Montenegrins is not an ethnic one; rather, it is a question of ideology and identity.

In Croatia, or Bosnia, or Kosovo, there is a clear ethnic line between the different communities, so that, for example, you have Serbian and Croatian majority villages with clearly identifiable cultural and ethnic markers. In Montenegro, you have both self-identified Serbs and self-identified Montenegrins in many Montenegrin families, which makes the whole experience of ethnic identity a matter of political and social, and even of family identity. Siblings who have the same parents might identify themselves differently, where one brother is a 
Serb while another is a Montenegrin. Such situations are not the exception in Montenegro, but rather more the rule, as the choice of identifying as Serb or Montenegrin in Montenegro is complex, personal, and not easily labeled. Something Montenegrin political scientists call "statehood-related cleavage".

\section{THE SERBIAN GOVERNMENT}

The Serbian government exploits identity in Montenegro and provides financial support for Serbian organizations in Montenegro. The beneficiaries of this support include Matica Srpska, which is a cultural institute promoting Serbian language and literature, as well as identity; the "Serbian House" in Podgorica; the Serbian media; as well as networks of Orthodox youth organizations, and so on. During the pro-church protests of 2020, Serbian officials engaged actively in the campaign. The Serbian Foreign Minister called Montenegro "a Serbian state", while the Serbian Defense Minister called for the unification of the Serbian world ("Srpski svet") ${ }^{10}$, a new name for the project of Greater Serbia, which is loosely based on the Russian concept of Russkiy mir. Of particular interest is Serbian House, an institution based in Podgorica that has an annual budget of 3.4 million euros which is mostly provided by the Serbian government i.e. Serbian taxpayers. The very same Serbian House was the official election campaign $\mathrm{HQ}$ of the new Montenegrin PM for the elections in August 2020.

Meanwhile, the Serbian government is attempting to exercise control over Montenegro's resources and economy. Examples of this include:

1. The placement of proxies with ties to the Serbian ruling party of Aleksander Vucic in positions of influence or control in the state Electricity Company (EPCG) and the National Parks of Montenegro ${ }^{11}$.

9. Jelena Dzankic (2013) Cutting the mists of the Black Mountain: Cleavages in Montenegro's divide over statehood and identity, Nationalities Papers, 41:3, 412430

10. https://www.aljazeera.com/news/2021/7/19/critics-condemn-ministers-callto-unite-serbian

11. https://www. vijesti.me/kolumne/543087/vucicev-pokusaj-drzavnog-udara 
2. The planned sale of EPCG to the Serbian state Electrical Company (EPS) ${ }^{12}$.

3. The plans that have been drawn up for the Buk Bijela Hydro Powerplant on the River Drina close to the Montenegrin border (created by the authorities in Serbia and Republika Srpska) will have a considerable impact on the downstream environment in Montenegro. ${ }^{13}$

4. The takeover of the national media scene by the Serbian state-owned company Telekom through a connected company called Kopernikus ${ }^{14}$. Bratislav Stoiljkovic, a businessman close to

5. Vucic bought Radio Jadran and the A1 TV channel. ${ }^{15}$ They also use the Serbian state-owned telecommunication company to influence media in Montenegro through the abundant resources they use for marketing purposes.

6. The purchase of the Port of Bar is perceived by many as a long-standing strategic goal for Serbia ${ }^{16}$

Against this background, those eager to preserve Montenegro's political and economic independence from Serbia view the "Open Balkan" regional economic integration project with suspicion. They believe that the project will create an uneven playing field and lead to economic and political subservience to Serbia.

\section{THE SERBIAN MEDIA}

The Serbian media scene is among the most illiberal in the region. Except for certain cable networks and few independent

12. https://www.portalanalitika.me/clanak/prodajom-elektroprivrede-eps-ucrna-gora-postaje-ekonomski-zavisna-od-srbije

13. https://balkaninsight.com/2020/06/29/un-may-resolve-bosnia-montenegropower-plant-dispute/

14. https://balkaninsight.com/2018/12/04/serbian-ruling-party-linked-companybuys-two-tv-stations-12-04-2018/

15. https://www.pobjeda.me/clanak/vujovic-u-toku-pregovori-o-jos-jednojvelikoj-kupovini

16. $h t$ ttps://www.b92.net/eng/comments.php?nav_id=96535 
outlets, most tabloids habitually spread government propaganda. Twitter recently labeled a dozen of these privatelyowned newspapers as state-affiliated ${ }^{17}$. This infamous propaganda machinery was used during the election campaign in Montenegro to raise tensions and to support Serbian Church demands during the protests of 2020. The Atlantic Council's Digital Forensic Center monitors Serbian media ${ }^{18}$ and they counted 14000 negative articles about Montenegro during the first months of 2020 .

The Serbian state and its' proxies have also financed Serbian media in Montenegro. Dozens of news portals have popped up over recent several years with a clear pro-Serbian and proRussian agenda, most notably the IN4S portal, whose editor, for example, participated in separatist campaigns in Ukraine. This web portal is the third most popular media outlet in Montenegro according to SimilarWeb. It was founded by the Montenegrin University Professor and former Head of Matica Srpska in Montenegro, Vladimir Božović. After the elections, he was of course rewarded for his "good work" for the Serbian and Russian cause. He became the Rector, the head of the Montenegro State University, the largest and the only state-run university in the country.

\section{SERBIAN NON-STATE ACTORS}

Another resource that is often used for mobilization is football fans or more specifically organized groups of hooligans. Belgrade-based football clubs such as Partizan and Red Star were widely popular across Yugoslavia, and these fans associations were used for the radicalization of young people. Most of the young football fans became members of the Orthodox youth chapters in Montenegrin towns and cities.

\section{INFLUENCE - TACTICS AND METHODS}

Through the well-known tactics mostly used by the Russian authorities, media reports, trolls, and bots on social networks

17. https://www.euronews.com/2021/08/18/serbian-president-vucic-slamstwitter-over-state-affiliated-media-labels

18. https://dfcme.me/en/yearly-analysis-the-serbian-media-about-montenegro/ 
have been used to induce panic and manipulate the religious feelings of the Montenegrin population. Public gatherings and road blockades were organized, which is something Croatia experienced 30 years ago. Apart from these well-known tactics, new methods were introduced. Civil society organizations for human rights and minority rights were used to manipulate and distort the image and perception of the church protests in Montenegro. It seems clear that they even infiltrated one LGBT organization that has been used to "pinkwash" nationalists and genocide deniers in Montenegro.

\section{ANALYSIS OF THE ELECTION RESULTS}

\section{a. The composition of the ruling majority}

When the moderate parties of all ideologies formed the blackred-green coalition in Germany to prevent the extremist AfD from reaching executive powers, somebody realized that those are the colors of Kenya and Afghanistan flags, and the terms "Afghan coalition" and "Kenya coalition" became part of the everyday political vocabulary in Germany.

The only difference with the Montenegrin "Afghan coalition" is that the darkest shades of black, similar to the AfD in Germany, are not only present within it; they are the core of the new majority in Montenegro.

In the aftermath of the Montenegrin elections, there were analyses in local and international media that were calling the new majority "colorful", "diverse" and "contradictory".

b. Unrest and attacks on minorities

On the night of the elections in late August 2020, "celebrations" took place across Montenegro. Some of the features of these celebrations included the singing of Serbian war songs, the prominent display of Serbian flags, calls for genocide against Albanians and Bosniaks, and attacks on mosques and Islamic community offices in the north of Montenegro. 


INFLUENCE ON GOVERNMENT'S POLICIES
Prime Minister Zdravko Krivokapic continues to employ pro-
Western rhetoric; he is aware that maintaining good relations
with the EU and the US is critical for remaining in power. While
Krivokapic opposes Serbian President Aleksandar Vucic, he
often accedes to the demands of the Serbian Orthodox Church
(SOC) - including accepting its long-term educational strategies
to promote Serbian identity. The view of many Montenegrins is
that the SOC is pursuing its long-term goal of creating a Serbian
majority in Montenegro, by appointing individuals from its "pool
of experts" to strategic positions, while gradually introducing
classes of religion in public schools and promoting Serbian
identity through changes to both the school and university
curriculums.
Against this background, those eager to preserve Montenegro's
political and economic independence from Serbia view the 'Mini-
Schengen' regional economic integration project with suspicion.
They believe that the project will create an uneven playing field
and lead to economic and political subservience to Serbia.
Another area of potential concern is the proposals for changes
to the Law on Citizenship and Residence. Under the draft plans,
it seems the government is seeking to ethnically engineer future
election results. This is clear in the apparent double standard of
automatically granting citizenship and thus voting rights, to
ethnic Serbian refugees from Bosnia, Croatia, and Kosovo, and
by simultaneously denying voting rights to Montenegrin citizens
living abroad (who are mostly Bosniaks and Albanians). Some
rough estimates are that this could affect the number of voters
by perhaps as much as $20 \%{ }^{19}$. An electoral body of that type
might grant pro-Serbian parties a $2 / 3$ majority and thus open the
path to possible changes to the Montenegrin constitution,
particularly changes to state symbols and so forth.

19. http://www.rtcg.me/vijesti/politika/316554/vlada-spremila-etnickiinzenjering-u-cg.html 


\section{CHANGES IN THE MONTENEGRIN NATIONAL SECURITY APPARATUS}

Here, it is perhaps best to illustrate the changes in the Security Apparatus by providing a few specific examples of changes in staffing and management in the sector:

A lawyer who is very close to the SOC was appointed as the Head of the Agency for National Security, with responsibility for the Montenegrin secret service, and in particular its relationship with other NATO member states in terms of sharing data and classified information. There have been allegations that as a result, the security services of other countries, most notably Serbia, now have unrestricted access to Montenegrin files and classified data.

A man who was convicted of being involved in the 2016 coup attempt, who has close ties to Russian extremists, and who has publicly praised Vladimir Putin, is now Head of the Parliamentary Committee on Defense and Security, and thus also a Member of the Council for National Security.

In early 2021 , a military officer who had been removed from a Montenegrin NATO Mission in Latvia, after it was discovered that he had tampered with confidential documents, was promoted to be part of the top management of Montenegrin military intelligence.

Most worryingly, certain classified information on the intelligence network and goals of various NATO partners were leaked to the Parliamentary Committee on Defense, apparently as a result of an "administrative oversight". It has been suggested over recent months that certain NATO members are now reluctant to share classified information with Montenegro, for fear that the data will leak.

\section{CONCLUSION - CHANGES IN THE MONTENEGRIN SOCIAL FABRIC}

Political changes are influencing changes in Montenegrin social fabric. By providing platforms for the spreading of radical narratives, Serbian and Russian actors are endorsing radical political entities in the country. Some of the polls and 
researches ${ }^{20}$ are showing the gap between political poles is growing extremely.

The percentage of those who perceive themselves as being on the "pro-Serbian side" has increased at the expense of ambivalence, while the percentage of those who see themselves on the "pro-Montenegrin" side has remained the same. Thus, essentially, the number of people who were undecided as to their preference has reduced and the number who are now "proSerbian" has considerably increased.

The percentage of those who consider themselves religious has increased by almost $30 \%$ since 2018

Within the Orthodox population, over one-third do not want to have to choose between the Montenegrin Orthodox Church and the Serbian Orthodox Church. There is a strong correlation between "pro-Serbian" identity and SOC affiliation The nationally ambivalent part of the population adopts to a greater extent the views of the Serbian Orthodox Church.

There is a growing tendency for historical revisionism and relativization of the nationalist collaboration with the fascist occupying forces during World War II (Serbian Chetnik and The Greens movement).

The government produces and insists on unpopular policies which are creating divisions in Montenegrin society. While they are doing their best not to overstep the red lines in foreign policy, especially when it comes to partnership with the West - EU and NATO, in domestic politics they are placing pro-Russian and pro-Serbian in key positions in education, security apparatus, culture, who are creating additional inter-ethnic tensions in an already divided society.

20. http://cgo-cce.org/en/2021/10/25/cg-puls-opominje-na-otudenostpoliticara-od-baze-i-lose-trendove/\#. YZFEIWDMJPZ 


\section{REFERENCES}

1. https://www.bellingcat.com/resources/podcasts/2020/06/16/b ellingchat-episode-3-hunting-the-the-salisbury-poisoningssuspects/

2. https://www.nytimes.com/2019/05/09/world/europe/montene gro-coup-plot-gru.html

3. https://hr.rbth.com/travel/86156-nasa-reportaza-cecenija

4. https://ria.ru/20170228/1488903745.html

5. Kudors, Andis "'"Russian World"-Russia's Soft Power Approach to Compatriots Policy" (PDF). Russian Analytical Digest. Research Centre for East European Studies. 81, (16 June 2010).

6. https://balkaninsight.com/2020/02/26/russian-backed-bishopjoins-montenegro-church-protests/

7. https://m.cdm.me/arhiva/izbori-2018/predsjednicki/ruskikonzul-dukic-osnivac-milaciceve-prave-crne-gore/

8. https://www.rbc.ru/society/02/11/2021/6180c9b29a7947b0f7 e6a9b9

9. Jelena Dzankic (2013) Cutting the mists of the Black Mountain: Cleavages in Montenegro's divide over statehood and identity, Nationalities Papers, 41:3, 412-430

10. https://www.aljazeera.com/news/2021/7/19/critics-condemnministers-call-to-unite-serbian

11. https://www.vijesti.me/kolumne/543087/vucicev-pokusajdrzavnog-udara

12. https://www.portalanalitika.me/clanak/prodajomelektroprivrede-eps-u-crna-gora-postaje-ekonomski-zavisnaod-srbije

13. https://balkaninsight.com/2020/06/29/un-may-resolve-bosniamontenegro-power-plant-dispute/

14. https://balkaninsight.com/2018/12/04/serbian-ruling-partylinked-company-buys-two-tv-stations-12-04-2018/

15. https://www.pobjeda.me/clanak/vujovic-u-toku-pregovori-ojos-jednoj-velikoj-kupovini

16. $h$ ttps://www.b92.net/eng/comments.php?nav_id $=96535$

17. https://www.euronews.com/2021/08/18/serbian-presidentvucic-slams-twitter-over-state-affiliated-media-labels

18. https://dfcme.me/en/yearly-analysis-the-serbian-mediaabout-montenegro/ 
19. http://www.rtcg.me/vijesti/politika/316554/vlada-spremilaetnicki-inzenjering-u-cg.html

20. http://cgo-cce.org/en/2021/10/25/cg-puls-opominje-naotudenost-politicara-od-baze-i-losetrendove/\#.YZFEIWDMJPZ 